\title{
Study on the Reform of State-owned Assets Management System
}

\author{
Yan Wan ${ }^{1}$, Yuan Qian ${ }^{2}$ \\ ${ }^{1}$ Nanchang Institute of Science \& Technology, Nanchang, Jiangxi, 330108
}

KEYWORDS: State-owned Assets; Management System; System Reform

\begin{abstract}
Since the 1978 reform and opening up, China's state-owned assets management system has changed several times, continuing to explore the establishment of the socialist market economy, state-owned assets management system deepening understanding. However, the new state-owned assets management system prototype, there are still some theoretical and practical issues yet to resolve, there is still a lot of operational issues need further clarification. Further Improving the State Property Management System is of great theoretical and practical significance.
\end{abstract}

\section{Introduction}

State-owned assets are owned by the State of the sum of all the property and property rights. State-owned assets have narrow and broad points. Narrow concept of state-owned assets in economics "capital" concept, the concept of accounting rather than the assets, refers to the state as investor-owned enterprises in accordance with the law and the interests of capital, also known as the operating state-owned assets. Operate state-owned assets, including: state-owned assets, administrative institutions possess and are transferred to profit and asset management purposes, as well as investment in state-owned resource assets management of the production process. Operating state-owned assets is not equal to the total assets. But state-owned assets management of state-owned capital mainly refers to, corporate balance sheets are in the owner's equity part, it also has the general characteristics of the capital, that the value of property, value, liquidity and cumulative.

From a different perspective, the state-owned assets can be divided into the following different categories. (1) Exist in the form of state-owned assets from the point of view, it can be divided into two kinds of tangible and intangible assets. Tangible assets are assets with the value of form and physical form, including land, buildings, machinery and equipment and a variety of raw materials. Intangible assets are controlled by a special body, it does not have the physical form and can provide the user with certain rights of the assets in a given period, which includes intellectual property rights, trademark rights, land use rights, non-patented proprietary technology, goodwill, etc. (2) To be distinguished from the form of state-owned assets, it can be divided into: Form of state-owned assets of enterprises, is the state-owned enterprises; Public goods aspect of state-owned assets; Monetary forms of state-owned assets; Resources owned assets form. (3) From considering the purpose and nature of the state-owned assets generally can be divided into operating state-owned assets, non-operating assets and resources of the state-owned assets into three categories.

\section{General Function of the Presence of State-owned Assets}

Make up the function of market failure. In a market economy, the market monopoly, there is a supply of public goods, externalities, information asymmetry and other factors make the market 
regulation of resource allocation failure, less than optimal allocation of resources. In this case, the government must implement the necessary economic policies, including the formation of state-owned enterprises directly in order to correct the market failure. For example, postal services, telecommunications, gas, water and other utilities and railways, highways, aviation terminals and other infrastructure, has obvious characteristics of public goods. Large investment needed for these industries, slow recovery, and their wide range of services, high social benefits. The private sector is rarely enter, it can only be entered by the state-owned assets by the government's Public Utilities Board to run or state-owned enterprises.

Macroeconomic stabilization function of Western classical economics that the market mechanism itself can often make markets in a stable state. The Great Depression of the 1930s, so that such a conclusion is seriously challenged. To achieve macroeconomic stability, full employment and price stability, the government must play a role in the macro-economic control. In order to strengthen efforts to control government macroeconomic policies in many countries the basic industries sector in the national economy established a number of state-owned enterprises, in order to ensure the implementation of the national macro-control policies.

Play a leading role in economic growth is GDP growth in GNP growth and economic development. Two important factors of economic growth are: increasing the productivity of factors of production and increase the supply of factors of production. To increase the supply of factors of production and improve the productivity of factors of production, in addition to institutional factors, the key lies in technological progress. This conclusion has been two US economists Solow and Denison confirmed through technological advances contribute to the US economy long-term growth of the Institute. To improve the productivity of factors of production, we must continue to adopt advanced equipment, promotion of technological invention and innovation, improve the quality of workers, so that the transfer of workers from low labor productivity sectors to high-productivity sectors of labor, that is, industrial restructuring and upgrading. These are the same government's economic policies and strong support is inseparable. Especially after World War II, the development of new technological revolution, the struggle for the nations of the world science and technology high ground Yueyan Yue column, many countries direct government investment to develop high-tech industries; to increase investment in education and vocational training to improve labor quality. For example, the United States in science and technology constantly breakthrough, it has been a world leader, and led to the rise of new industries sector, changing the industrial structure of the entire country. This is the US federal government has invested heavily in technology and other scientific research and education inseparable.

Play an important role in the international competition in today's world economic integration process, each country plays a role in the international division of labor, and through a variety of market linkages become an integral part of the world economy. Although the theory of free trade is very popular, the voice of free trade are on the rise, but in the actual external relations, in order to occupy a place in the fierce international competition in the market, protectionist policies of governments constantly. Through tariffs and non-tariff trade barriers to protect their own economic strength of the state economy through supporting to protect their own basic industries, the growth of infant industries in order to increase the strength of the national industry. Of course, this approach should be appropriate and whether the person would be counterproductive.

Consolidate economic system of state-owned assets of the presence of functional capabilities in addition to the above economic factors, as well as political factors: the class nature of the ruling class interests. For example, China is a developing socialist country, the state-owned economy is the foundation of the socialist political system and economic system is capitalist private ownership 
and exploitation of the relationship between fundamental negation, the state-owned economy to play a leading role in the national economy, to develop and strengthen the state economy.

\section{Measures of State Assets Management System Reform}

The country's national conditions of reform. Reform must proceed from its own national conditions, do not expect a generally applicable only correct path to follow. As China has successfully carried out and continue as in the economic reform, the reform of state-owned assets management system should also be gradual. In this regard, Russia has had a profound lesson. In addition, China's economic development imbalance decision no universal model, avoid across the board, blind windy. Even determine the direction of reform, if they can fully take into account the impact of path dependence, also will greatly reduce the risk of failure.

Create a favorable environment for state-owned assets management system. Excellent developed market economies state-owned assets management of the environment, in addition to a complete legal system, improves financial market development, social security system, government function properly. Such as social security system, the West after decades of development and has formed a "social assistance", "social insurance", "social welfare" three complete range of the sound system. Western countries, comprehensive social security, not only solved the basic living conditions of citizens, and on this basis provide the highest possible social welfare for citizens. Improve the social security system reform of state-owned economy to play a role is unique because there is this support for the state-owned economic reform in Western countries is not much resistance, it did not cause social unrest. Improve the social security system plays the role of a stabilizer, and the development of sound financial markets, complete legal system, appropriate government function together to form a good environment of state-owned economic reform.

Separate government from enterprises. Separate government from enterprises as well as the separation of ownership and management, the state-owned enterprises really thoroughly into the market, is the primary goal of state-owned assets management system. There is no doubt that, in theory, privatization is the path to achieve this goal. However, China's reality tells us that the basis of the ruling political ideas and not to mention the ruling party has its own internal requirements, even from the growing status of the private economy, the development scale of private capital, entrepreneurs, state of maturity of the market, social security and affordability the general attitude of the public, and many other conditions, the large-scale privatization of the large state-owned enterprises, especially large-scale privatization of the timing is far from mature, and therefore need to find another solution.

The Authority must be made public. Effectiveness of supervision is its openness. In order to prevent insider information asymmetry may lead to control problems, the practice should learn from Singapore. In fact, the state-owned enterprises listed on whether or not that business conditions should be made public. At the same time, media monitoring and agencies is an important and effective way. Public opinion and the media as a barometer of business conditions, due to the correspondent of the pervasive, any irregularities adventure will pay a very high cost and price.

Classification of state-owned assets management from the face of the introduction of foreign state-owned assets management system features can be seen that category management is a common feature of countries in the management model. As a state-owned assets property right, which have a multiplicity of behavioral targeting. These national goals necessarily reflected in the operation of state-owned assets. However, due to not having a unity between these objectives may conflict with each other, such as profit and social goals of the conflict. Therefore, a better approach is to classify state-owned assets, respectively, so as to assume different goals. 


\section{Conclusion}

Chinese state-owned assets management system more than two years continue to deepen reform, a new framework for state-owned assets management system has begun to take shape, owned Assets Supervision paying off. However, the new state-owned assets management system there are still some theoretical and practical issues yet to resolve, there is still a lot of operational issues need further clarification. Further improve the State-owned Assets Management System is an urgent problem that we must face.

\section{Reference:}

[1] Dong Haowei. Ways formation when authorized management of state-owned capital expansion hook selection [J]. State-owned Assets Management 2003, 3.

[2] Reginal: Construction of new issues related to state-owned system [J]. state-owned assets management, in 2003 (4), 44-51.

[3] Guo Gu, Zhang Tianyang. State-owned Assets Management Principal - Agent Problem Analysis [J]. Theory and Practice of Finance and Economics, 2003.

[4] Wu Jinglian. Strategic reorganization of state-owned economy [M]. Beijing: China Development Press, 1998.

[5] Sun Xiulan, Li Aihua. Construction of state-owned assets management budget management system [J]. for Fiscal Studies, 2002, (5). 